||||||||||||||||||||||||||||||||||||

\title{
研究論文
}

|||||||||||||||||||||||||||||||||

\section{急冷凝固した $\mathrm{Al}-1.8 \% \mathrm{Cr}-1.7 \% \mathrm{Zr}$ 合金の時効析出}

\author{
谷口 靖* ·古城 紀雄** \\ 田井 英男 $* * *$. 堀 茂徳 $* *$
}

\begin{abstract}
Precipitation behavior during aging in a rapidly
\end{abstract}
solidified $\mathrm{Al}-1.8 \% \mathrm{Cr}-1.7 \% \mathrm{Zr}$ alloy

Yasushi TANIGUCHI* Norio FURUSHIRO**

Hideo TAI $^{* * *}$ and Shigenori HORI**

Age hardening behavior and precipitation structures were investigated for ribbons mainly of both an $\mathrm{Al}-1.8 \% \mathrm{Cr}-$ $1.7 \% \mathrm{Zr}$ alloy and the alloy with the further additional element of $\mathrm{Si}$, which were prepared by a rapid solidification method using a single roll. Then, the role of $\mathrm{Cr}$ or $\mathrm{Si}$ in the precipitation hardening process has been examined.

As a result, age hardening took place more remarkably in the $\mathrm{Al}-1.8 \% \mathrm{Cr}-1.7 \% \mathrm{Zr}$ alloy than that in a $\mathrm{Al}-1.7 \% \mathrm{Zr}$ binary alloy. It is condidered that this is caused by the precipitation of fine and spherical particles of the metastable $\mathrm{Al}_{3} \mathrm{Zr}$ phase with the $\mathrm{Ll}_{2}$ structure, which has been made possible because the additional element of Cr retards the precipitation with the grain boundary reaction. By the addition of $\mathrm{Si}$, together with $\mathrm{Cr}$, to the $\mathrm{Al}-1.7 \% \mathrm{Zr}$ alloy, the precipitation of the fine and spherical particles of the metastable phase has been accelerated. Thus, the addition of Si results in reaching higher values of the peak hardness.

Keywords: precipitation, aging, $\mathrm{Al}-\mathrm{Cr}-\mathrm{Zr}$ alloy, rapid solidification, metastable phase

(Received August 26, 1986)

\section{1. 緒言}

$\mathrm{Al}-\mathrm{Zr}$ 合金を時効して準安定の $\mathrm{Ll}_{2}$ 型 $\mathrm{Al}_{3} \mathrm{Zr}$ 規則相を 微細に析出させると $\mathrm{Al}$ の高温強度が著しく高くなるの で, $\mathrm{Al}-\mathrm{Zr}$ 二元合金 ${ }^{1)}$ 执よび，これにさらに微量第 3 元 素を添加して析出過程が調べられてきた ${ }^{2), 3)}$ 。最近にな つて比較的多量の $\mathrm{Cr}$ を含む $\mathrm{Al}-\mathrm{Cr}-\mathrm{Zr}$ 合金のすぐれた 耐熱性が注目され，急冷凝固した $\mathrm{Al}-\mathrm{Cr}-\mathrm{Zr}$ 合金粉末を 押出加工したものは高温強度の大きいことが報告されて (るる4),5)。しかしながら, $\mathrm{Al}-\mathrm{Zr}$ 合金の析出過程に対す る $\mathrm{Cr}$ の影響についてはこれまでほとんど調べられてお らず, 従つて, $\mathrm{Al}-\mathrm{Cr}-\mathrm{Zr}$ 合金の加熱に伴う時効析出に ついては未だ解明されていない。他方, 固溶限以上の $\mathrm{Cr}$ を含む $\mathrm{Al}-\mathrm{Cr}$ 合金ではその再結晶温度が著しく高く
なるとされている6)。本研究では $\mathrm{Al}-\mathrm{Cr}-\mathrm{Zr}$ 合金の析出 過程を明らかにしようとしたが，このことは本系合金の 急冷㠜固粉末を高温押出する際にも有用な資料を与える と考学られる。

そこでまず急冷凝固によつて Cr および $\mathrm{Zr}$ を強制固 溶した $\mathrm{Al}-1.8$ mass $\% \mathrm{Cr}-1.7$ mass $\% \mathrm{Zr}$ 合金*を作製し， これについて 623〜 723 K にわたり時効析出を調べるこ とにした。

\section{2. 実験試料および方法}

純度99.998\%の $\mathrm{Al}$ と $99.99 \% \mathrm{Cr}$ および $99.7 \% \mathrm{Zr}$ とを 用いて $\mathrm{Al}-10 \% \mathrm{Cr}$ 㧊よび $\mathrm{Al}-10 \% \mathrm{Zr}$ 母合金を真空溶解

* 以後, 単に\%と記す。

* 大阪大学大学院工学研究科 (吹田市)。Graduate School of Engineering, Osaka University (Suita).

** 大阪大学工学部金属材料工学科 (吹田市)。Department of Materials Science and Engineering, Faculty of Engineering, Osaka University (Suita).

*** 富山工業高等専門学校金属工学科（富山市）。Department of Metallurgical Engineering, Toyama National College of Technolgy (Toyama). 
鋳造によつて作製した。また， $\mathrm{Al}-\mathrm{Cr}-\mathrm{Zr}$ 合金に微量の Siを添加することによる影響をも調べるために， 99.999\% Si を用いて同様に $\mathrm{Al}-4 \% \mathrm{Si}$ 母合金をも作製し た。次にこれら母合金と純 $\mathrm{Al}$ とを小型炉で溶解して水 冷の銅鋳型を 2 枚並べた $2.4 \mathrm{~mm}$ 間隙にチルキャストし たものを片ロール法による急冷凝固用の試料とした。す なわち，このチルキャスト法で得られた合金から約 $2 \mathrm{~g}$ を切り出して黒鉛ルッボで溶解し，ルッボ下部のノズル から回転する銅製ロール上に噴出させてリボン状試料を 得た。リボン状試料の幅は $2 \sim 3 \mathrm{~mm}$, 厚さは約 $50 \mu \mathrm{m}$, 長さ数 $\mathrm{m}$ であつた。冷却速度は約 $10^{5} \mathrm{~K} / \mathrm{s}$ と見積もら れた。これを適当な長さに切り出してパイレックスガラ 不管に真空封入して，623，673および $723 \mathrm{~K} て ゙ 6$ min か ら $10^{3} \mathrm{hr}$ にたつて熱処理した。時効後の微小硬さの 測定には荷重 $10 \mathrm{~g}$ を用いた。このときの圧痕深さはリ ボン状試料の厚さの $1 / 10$ 以下であつた。

\section{3. 実 験 結 果}

\section{1 時効硬化}

はじめに $\mathrm{Al}-1.8 \% \mathrm{Cr}-1.7 \% \mathrm{Zr}$ 合金のリボン状試料に ついて電顕観察した。その給果 Fig. 1 のように何らの 晶出物も認められず $\mathrm{Cr}$ および $\mathrm{Zr}$ はともに $\mathrm{Al}$ 中に強制 固溶したと認められた。Fig. 2 は $\mathrm{Al}-1.8 \% \mathrm{Cr}-1.7 \% \mathrm{Zr}$ 合金のリボン状試料について $623 \mathrm{~K} て ゙$ 時効したときの 硬さをリボン状試料のロール接触面側と自由表面側とに ついて測定したものである。ロール面側, 自由表面側と もに $6 \mathrm{~min}$ の時効でわずかな硬化がみられ，200 hr 前後 で最高硬さに達し，その後軟化した。双方の時効硬化曲 線に大きな違いはないようである。急冷凝固したままの リボン試料の結晶粒度は自由表面側で平均 $3.2 \mu \mathrm{m}$ で口 ール面側では結晶粒度分布にやや広がりがみられた。こ れはロール面側では高速に回転するロールと溶湯との間 に空気をまき込むことがあつて，試料の冷却条件に場所

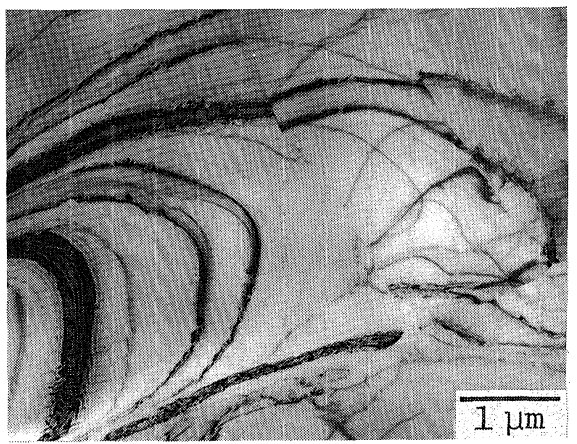

Fig. 1 Electron micrograph of the ribbon of an Al$1.8 \% \mathrm{Cr}-1.7 \% \mathrm{Zr}$ alloy, showing as rapidly solidified structure of the single phase.

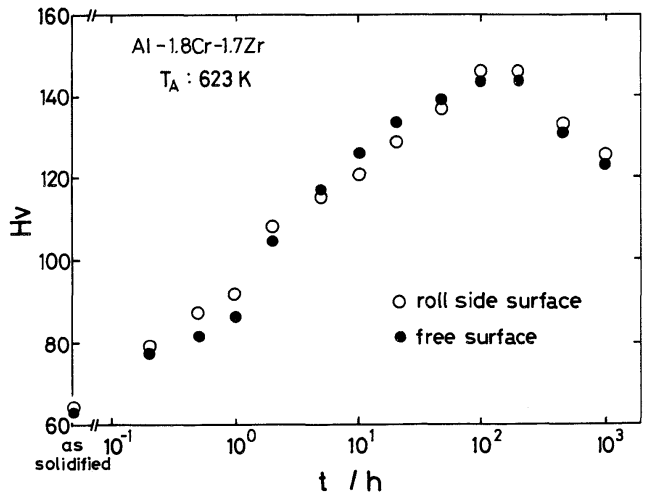

Fig. 2 Change in the Vickers hardness during aging at $623 \mathrm{~K}$ on both roll side surface and free surface of a rapidly solidified $\mathrm{Al}-1.8 \% \mathrm{Cr}-1.7 \% \mathrm{Zr}$ alloy.

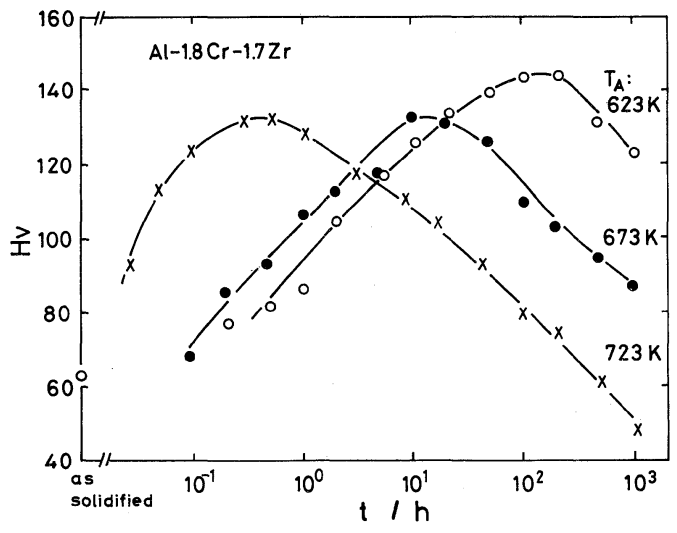

Fig. 3 Change in the Vickers hardness during aging at 623,673 and $723 \mathrm{~K}$ for a rapidly solidified Al$1.8 \% \mathrm{Cr}-1.7 \% \mathrm{Zr}$ alloy.

的な差異を生じたためと考えられる。またこのために ロール面側ではリボン状試料の平滑さが自由表面側より もやや劣つていた。以上のことから以後の硬さ測定は試 料の自由表面側についてのみ行らこととした。

Fig. 3 は $\mathrm{Al}-1.8 \% \mathrm{Cr}-1.7 \% \mathrm{Zr}$ 合金の623,673および $723 \mathrm{~K}$ での時効硬化曲線をまとめて示したものである。 3 つの時効温度について比較すれば温度が高くなると時 効硬化は短時間側で現われ，また時効温度の低い方が到 達最大硬さの值は高くなるよらである。Fig. 4 は Crを 含まない $\mathrm{Al}-1.7 \% \mathrm{Zr}$ 合金の時効硬化曲線である。 3 つ の時効温度ともに単調な硬化を示し，最高硬さの值はい ずれの温度とも $H_{V} 100$ 以下で，時効温度によるちがい が明瞭でない。 $\mathrm{Al}-1.8 \% \mathrm{Cr}$ 二元合金について同じく高 温加熱してみたが認知できるような時効硬化はみられな かつた。

Fig. 5 はそれを示す。図から明らかなよらに，Al一 


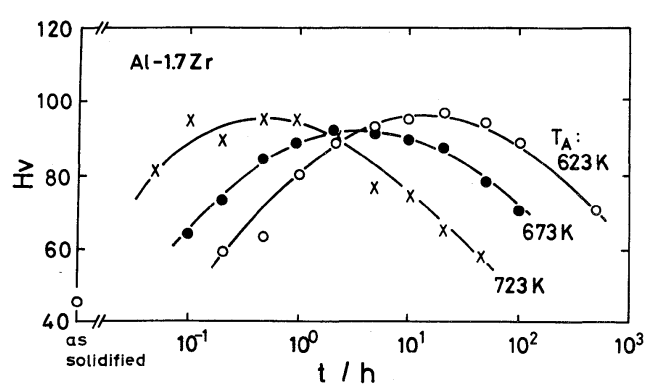

Fig. 4 Change in the Vickers hardness during aging at 623,673 and $723 \mathrm{~K}$ for a rapidly solidified $\mathrm{Al}-$ $1.7 \% \mathrm{Zr}$ alloy.

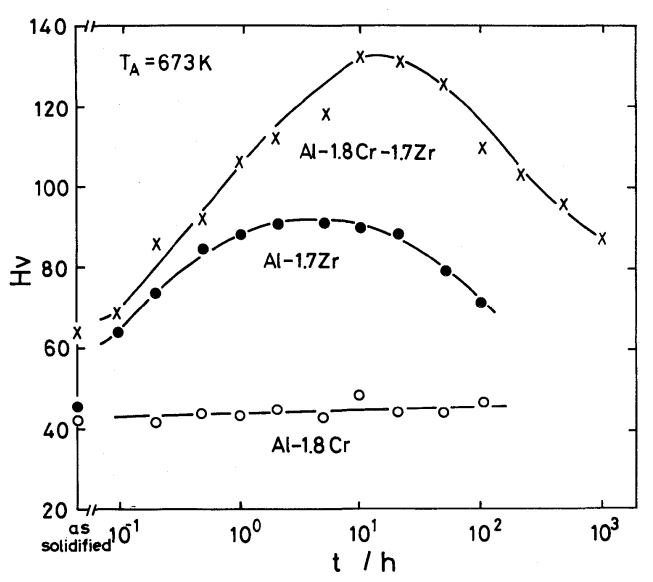

Fig. 5 Change in the Vickers hardness during aging at $673 \mathrm{~K}$ for rapidly solidified alloys of $\mathrm{Al}-1.8 \% \mathrm{Cr}$, $\mathrm{Al}-1.7 \% \mathrm{Zr}$ and $\mathrm{Al}-1.8 \% \mathrm{Cr}-1.7 \% \mathrm{Zr}$.

$1.7 \% \mathrm{Zr}$ 合金の時効硬化曲線はこれに $1.8 \% \mathrm{Cr}$ を加える ことにより更に高くなつており, かつ最高硬さに到達す る時効時間は $\mathrm{Al}-1.7 \% \mathrm{Zr}$ 合金のそれよりも長時間側に ずれている。上述のように $\mathrm{Al}-1.8 \% \mathrm{Cr}$ 合金は時効硬化 を示さないから， $\mathrm{Cr}$ の固溶硬化だけでは $\mathrm{Al}-1.7 \% \mathrm{Zr}$ 合 金に対する $\mathrm{Al}-1.8 \% \mathrm{Cr}-1.7 \% \mathrm{Zr}$ 合金の硬化は説明でき ない。すなわち，急冷凝固時の硬さをみると $\mathrm{Al}-1.8 \%$ $\mathrm{Cr}-1.7 \% \mathrm{Zr}$ 合金では $\mathrm{Al}-1.8 \% \mathrm{Cr}, \mathrm{Al}-1.7 \% \mathrm{Zr}$ のれぞ れの二元合金のそれよりも硬さの值が大きく，これらの おのおのは急冷凝固時における結晶粒度にそれ汪どの差 異がなかつたことから，Cr 拈よび $\mathrm{Zr}$ 原子の固溶硬化に 対応していると考えられる。 $\mathrm{Al}-1.8 \% \mathrm{Cr}$ 合金は時効時 間にかかわりなく硬さの変化が認められない。ここで $\mathrm{Al}-1.7 \% \mathrm{Zr}$ 合金の硬化曲線と $\mathrm{Al}-1.8 \% \mathrm{Cr}-1.7 \% \mathrm{Zr}$ 合金 の硬化曲線とが対応しないのは, $\mathrm{Cr}$ の添加が $\mathrm{Al}-\mathrm{Zr}$ 合 金の時効析出になんらかの影響を与えているためである と考えねばならない。そこで $\mathrm{Al}-\mathrm{Zr}$ 合金の時効硬化に 対する $\mathrm{Cr}$ の影響を調べるために, $\mathrm{Cr}$ 量をかえた $\mathrm{Al}-$ $\mathrm{Cr}-1.7 \% \mathrm{Zr}$ 合金について時効硬化を調べた。Fig. 6 に

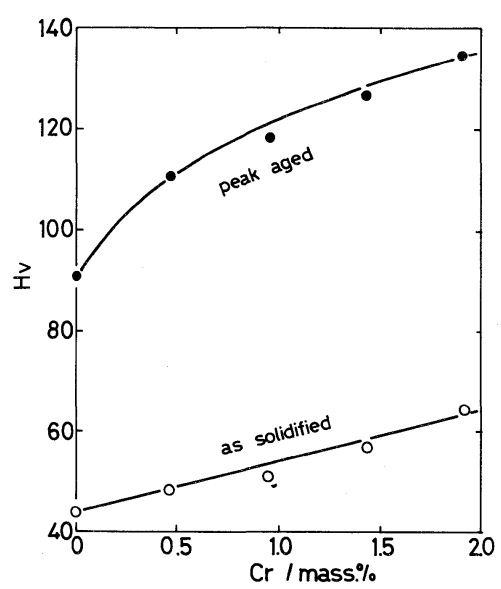

Fig. 6 Influence of $\mathrm{Cr}$ content on the hardness obtained at as solidified or the peak aged condition of $\mathrm{Al}-\mathrm{X} \% \mathrm{Cr}-1.7 \% \mathrm{Zr}$ alloys.

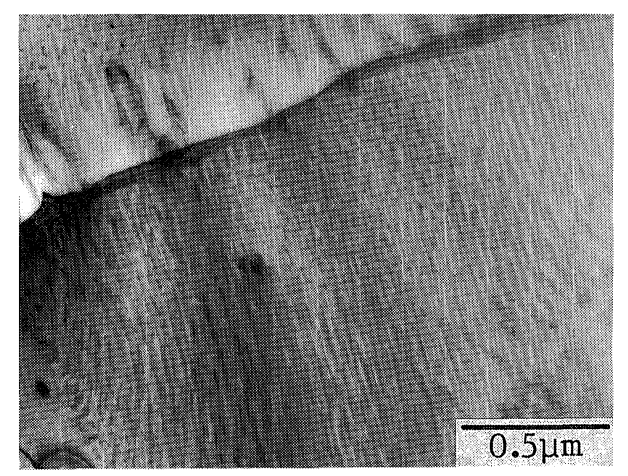

Fig. 7 Electron micrograph of an $\mathrm{Al}-1.7 \% \mathrm{Zr}$ alloy aged at $673 \mathrm{~K}$ for $5 \mathrm{~h}$ after rapid solidification, showing precipitation structure with grain boundary reaction over the whole specimen.

みるよらに, $\mathrm{Al}-1.7 \% \mathrm{Zr}$ 二元合金に対して $\mathrm{Cr}$ を添加す ると, 急冷凝固したリボン状試料の硬さの值は添加 $\mathrm{Cr}$ 量とともにほぼ直線的に高くなつている。Crを添加す ると $\mathrm{Al}-\mathrm{Cr}-1.7 \% \mathrm{Zr}$ 合金の時効硬化の最大值をも高く しているよらである。

\section{2 組織観察}

はじめに $\mathrm{Al}-1.7 \% \mathrm{Zr}$ 二元合金について時効試料の電 顕観察を行つた。本系合金についてこれまでの研究で認 められていると同様に, 本合金に沶いても粒界反応析出 の進展が速く, Fig. 7でみるように最高硬さを示す時効 時間では粒界反応析出が注ぼ試料全域をおおつている。 粒界反応析出域でみられる針状の細かい析出物は $\mathrm{Al}_{3} \mathrm{Zr}$ の準安定相で，地質とは整合であることが知られてい る1)。これまでの研究によると一般に粒界反応析出した 領域ではほとんど硬化しないといわれるが7), 本系合金 では粒界反応析出した準安定相が非常に細かいこと, 地 

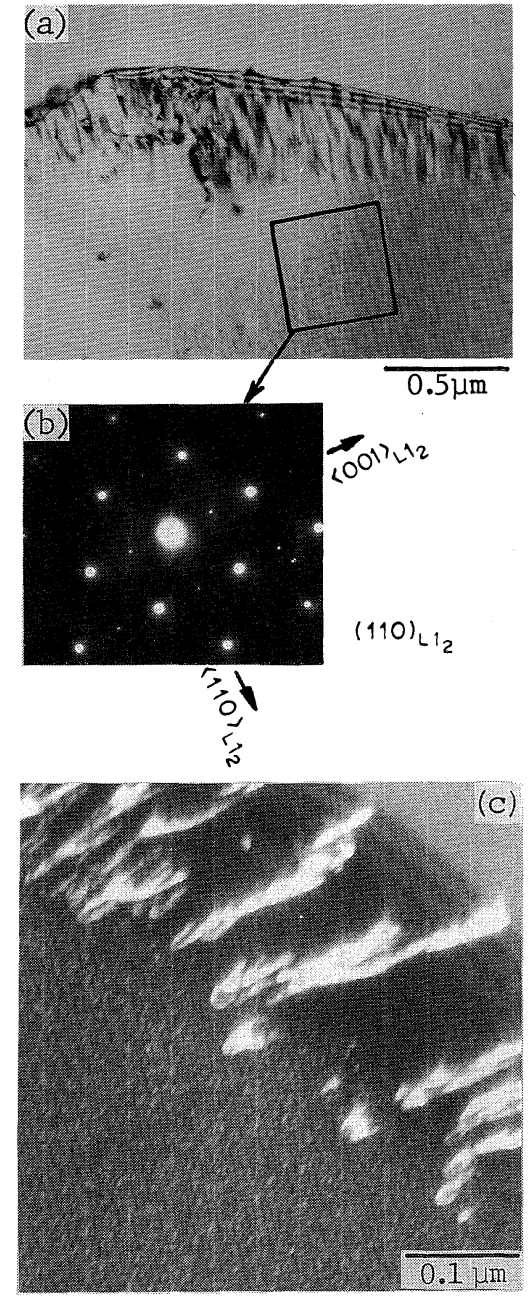

Fig. 8 Electron micrographs of an $\mathrm{Al}-1.8 \% \mathrm{Cr}-$ $1.7 \% \mathrm{Zr}$ alloy aged at $673 \mathrm{~K}$ for $10 \mathrm{~h},(\mathrm{a})$, the diffraction pattern for square area in (a), (b), and the dark field image with high magnification using a spot from the ordered phase in another area, (c). In the bottom left of (c), fine particles are shown, while precipitates with grain boundary reaction in the top right.

質と整合であることなどによつて粒界反応析出の進展と ともに硬化している。さらに時効時間を長くすると針状 の準安定析出物が時効中に分断され，それが次第に粗大 化していくこと抢よび平衡相の析出によつて軟化するこ とになる。ところが Fig. 8 の $\mathrm{Al}-1.8 \% \mathrm{Cr}-1.7 \% \mathrm{Zr}$ 合金 の最高硬さに対応する時効時間では, 粒界反応析出は試 料全域に及んでおらず，その進展範囲は限定されてい る。針状析出物のスペーシングもいくらか大きくなつて いるよらである。これに対して，Fig. 8(c)に粒界反応型 析出物とともに示すように, 結晶粒内では $\mathrm{Ll}_{2}$ 型の規則 構造をもつ $\mathrm{Al}_{3} \mathrm{Zr}$ の微細な析出物のあることがわかつた。

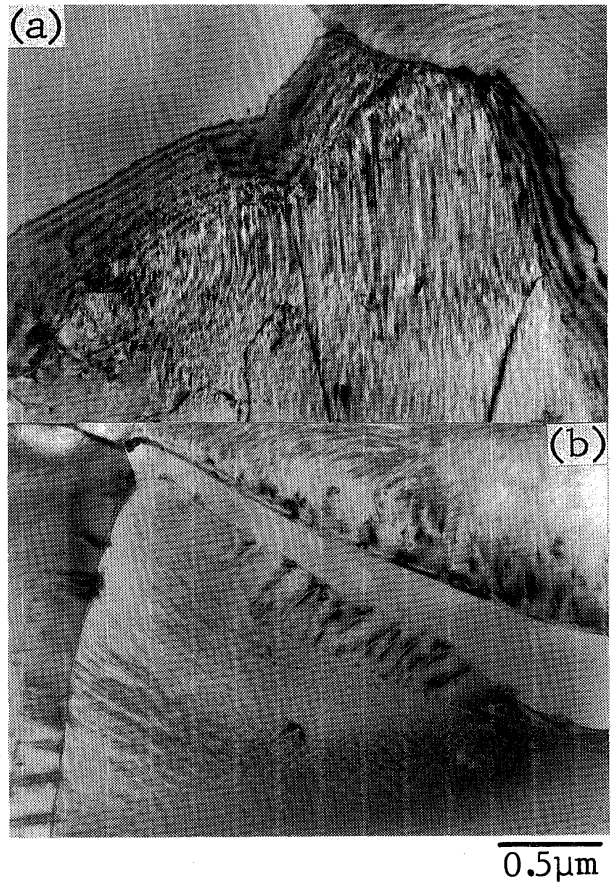

Fig. 9 Electron micrographs of (a) an Al-0.45\% $\mathrm{Cr}-1.7 \% \mathrm{Zr}$ alloy and (b) an $\mathrm{Al}-1.35 \% \mathrm{Cr}-1.7 \% \mathrm{Zr}$ alloy, which were aged at $673 \mathrm{~K}$ for $6 \mathrm{~min}$.

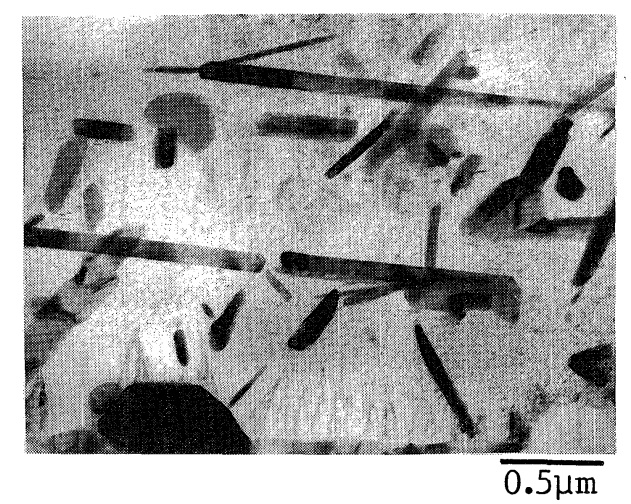

Fig. 10 Electron micrograph of an $\mathrm{Al}-1.8 \% \mathrm{Cr}-$ $1.7 \% \mathrm{Zr}$ alloy aged at $673 \mathrm{~K}$ for $10^{3} \mathrm{~h}$, showing precipitates including $\mathrm{Cr}$.

$\mathrm{Cr}$ の添加は $\mathrm{Al}-1.7 \% \mathrm{Zr}$ 合金の粒界反応析出の進展をお さえ，その結果結晶粒内で微細球状粒子が析出すること になつたと考えられる。

Fig. 9 は $\mathrm{Al}-0.45 \% \mathrm{Cr}-1.7 \% \mathrm{Zr}$ 合金と $\mathrm{Al}-1.35 \% \mathrm{Cr}$ $1.7 \% \mathrm{Zr}$ 合金をそれぞれ $673 \mathrm{~K}$ で $6 \mathrm{~min}$ 時効したときの 組織で， Cr 添加量が増えると粒界反応析出が少なくな つていることがわかる。また，Fig. 10 は Al-1.8\% Cr$1.7 \% \mathrm{Zr}$ 合金を $10^{3} \mathrm{hr}$ 時効した組織で，結晶粒内に平衡 相である $\theta$ 相 $\left(\mathrm{Al}_{7} \mathrm{Cr}\right)$ が板状に出していることがわか 

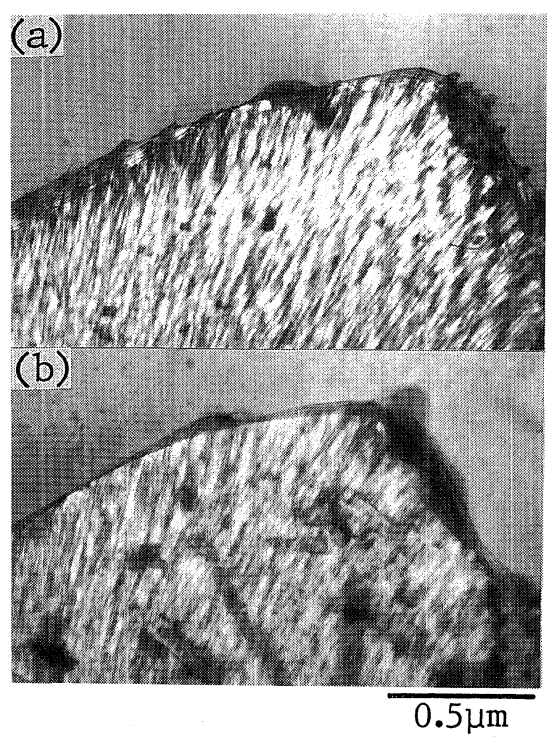

Fig. 11 Electron micrographs of an $\mathrm{Al}-1.8 \% \mathrm{Cr}-$ $1.7 \% \mathrm{Zr}$ alloy aged at $673 \mathrm{~K}$ for (a) $6 \mathrm{~min}$ and (b) $10^{2} \mathrm{~h}$ for the same area as (a).

つた。そこで $\mathrm{Al}-1.8 \% \mathrm{Cr}-1.7 \% \mathrm{Zr}$ 合金の同一試料につ いて注意深く真空加熱し，加熱の途中で同一箇所を電顕 観察した。Fig. 11 はそれで，粒界反応析出の進行は時 効初期で停滞している。反応先端には Cr 化合物の析出 がみられる。時効時間が長くなると粒界反応析出領域内 でも Cr 化合物の析出がみられるようになる。この領域 内での $\mathrm{Cr}$ 化合物は粒界反応析出物である $\mathrm{Al}_{3} \mathrm{Zr}$ 相之は 無関係に析出するようである。

\section{4. 考察}

$\mathrm{Al}-1.7 \% \mathrm{Zr}$ 合金では時効の初期から粒界反応析出が 進展し，さらに時効を続けるとやがて試料全面を粒界反 応析出が括拈つてしまう。 $\mathrm{Al}-\mathrm{Zr}$ 二元合金の粒界反応析 出の進行についての詳細は明確になつていないが, 急冷 凝固試料の粒界反応析出の進展の速いことはよく知られ ている。たとえばスプラット冷却した $\mathrm{Al}-6 \% \mathrm{Hf}$ 合金で は $358 \mathrm{~K}$ で粒界反応析出の進展するのが認められてい る8)。しかし $\mathrm{Al}-0.22 \% \mathrm{Zr}$ 合金 ${ }^{1)} 923 \mathrm{~K}$ で溶体化後に 水冷したものでは, その後の $723 \mathrm{~K}$ 時効で粒界反応析 出の体積率が数\%程度にとどまり, 長時間時効しても試 料全面を粒界反応析出が占めることはなかつた。粒界反 応析出は結晶粒界の移動に伴ら析出であるので7), 粒界 移動のし易さに深く関連すると考えられる。液体急冷合 金では粒界移動し易いことが知られている。なお粒界の 移動速度が大きいときには，この移動する粒界にほぼ直 角に配列した粒界反応析出物間の間隔は小さくなり，か つ粒界の移動が速いと粒界反応析出の進展した領域にお

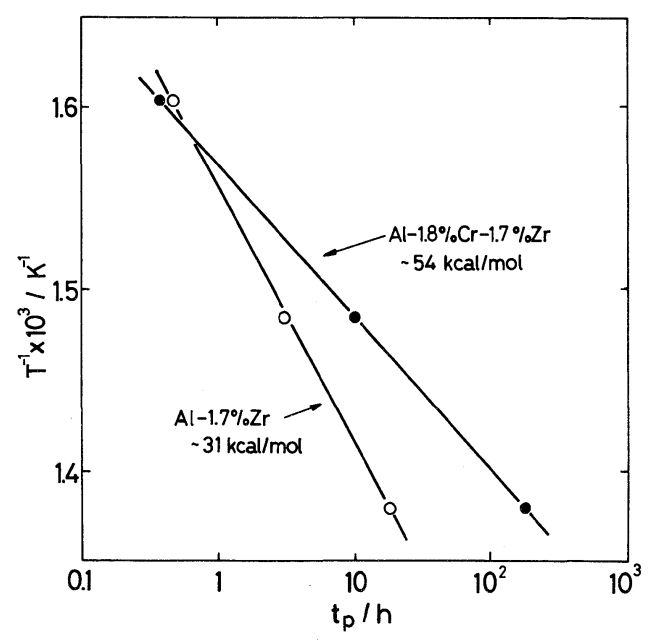

Fig. 12 Relationship between the logarithm of the aging time at the peak hardness and the reciprocal of the aging temperature for an $\mathrm{Al}-1.7 \% \mathrm{Zr}$ and an $\mathrm{Al}-$ $1.8 \% \mathrm{Cr}-1.7 \% \mathrm{Zr}$ alloys.

いて，なお過飽和度を残すことも考えられる7,99。

一方，1.8\%まで $\mathrm{Cr}$ を含む $\mathrm{Al}-\mathrm{Cr}$ 合金では時効硬化 を示さなかつたが， $\mathrm{Al}-1.7 \% \mathrm{Zr}$ 合金に Cr を添加すると $0.45 \%, 0.9 \%$ とr 量が多くなる汪ど $\mathrm{Al}-\mathrm{Cr}-\mathrm{Zr}$ 合金の 到達最高硬さ值は次第に高くなつた。そして Crを添加 すると粒界反応析出の進展は抑兄られた。その結果, 結 晶粒内で $\mathrm{Ll}_{2}$ 構造をもつ $\mathrm{Al}_{3} \mathrm{Zr}$ 粒子が析出した。つまり 単ロール法で急冷した $\mathrm{Al}-1.7 \% \mathrm{Zr}$ 二元合金の時効硬化 は粒界反応析出により，これに $1.8 \% \mathrm{Cr}$ を添加した $\mathrm{Al}-$ $1.8 \% \mathrm{Cr}-1.7 \% \mathrm{Zr}$ 合金では, 粒界反応析出による寄与は 小さく主として結晶粒内に析出する微細で球状の準安定 $\mathrm{Al}_{3} \mathrm{Zr}$ 相により硬化すると考えられた。

いま Fig. 4 の $\mathrm{Al}-1.7 \% \mathrm{Zr}$ 合金で最高硬さに到達する のに必要な時効時間と時効温度との関係をプロットする とFig. 12 となる。また $\mathrm{Al}-1.8 \% \mathrm{Cr}-1.7 \% \mathrm{Zr}$ 合金につ いても同様な関係を図中に示した。 $\mathrm{Al}-1.7 \% \mathrm{Zr}$ 合金の 析出過程は本実験の時効温度の範囲内では同様で時効硬 化は粒界反応析出で達せられると考えられるので, 直線 の傾斜から求められる $31 \mathrm{kcal} / \mathrm{mol} の$ 活性化エネルギ一 は粒界反応析出の活性化エネルギーを与えることになろ ら。この值は $\mathrm{Al}$ 中の $\mathrm{Zr}$ の体拡散の活性化エネルギー として与えられている51〜 $52 \mathrm{kcal} / \mathrm{mol}^{1), 3)}$ に比較してか なり小さい。また $\mathrm{Al}-1.8 \% \mathrm{Cr}-1.7 \% \mathrm{Zr}$ 合金について最 高硬度に到達する時効時間と時効温度との関係から求め た見かけの活性化エネルギーは $54 \mathrm{kcal} / \mathrm{mol}$ であつた。 結晶粒内にみられる球状準安定粒子の析出の活性化エネ ルギーは，たとえば析出粒子がある一定の大ささになる に必要な時効時間から求めることができる。本研究の実 験範囲内では結晶粒内の析出粒子径は小さくて電顕観察 


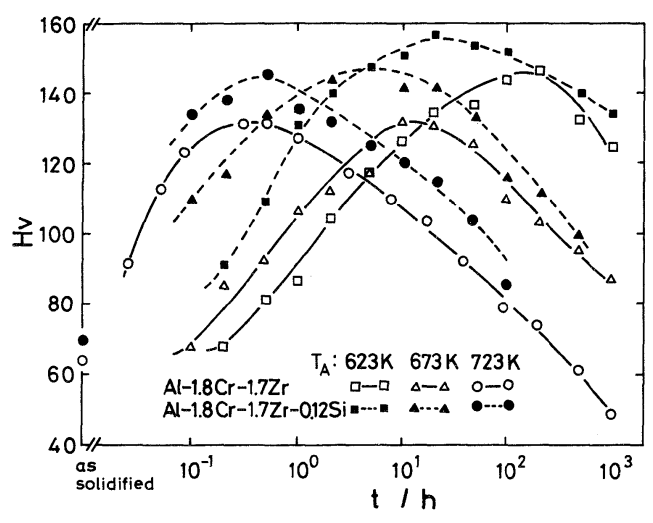

Fig. 13 Change in the hardness during aging at 623, 673 and $723 \mathrm{~K}$ for rapidly solidified alloys of $\mathrm{Al}-$ $1.8 \% \mathrm{Cr}-1.7 \% \mathrm{Zr}$ and $\mathrm{Al}-1.8 \% \mathrm{Cr}-1.7 \% \mathrm{Zr}-0.12 \%$ Si.

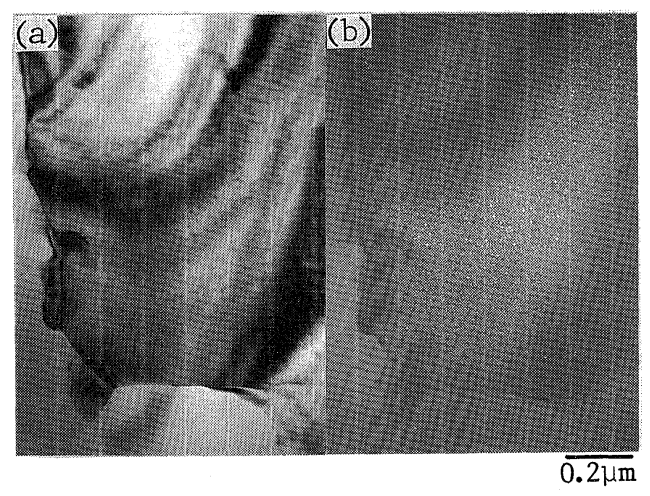

Fig. 14 Electron micrographs of (a) bright field and (b) dark field images for an $\mathrm{Al}-1.8 \% \mathrm{Cr}-1.7 \% \mathrm{Zr}-$ $0.12 \% \mathrm{Si}$ alloy aged at $673 \mathrm{~K}$ for $5 \mathrm{~h}$ after rapid solidification.

により粒子径を正確に求めることは困難であつた。そこ でこれらの析出粒子がある大きさになつたときに試料が 最高硬さを与えたと仮定するならば，直線の傾さから得 られた $54 \mathrm{kcal} / \mathrm{mol}$ は $\mathrm{Al}_{3} \mathrm{Zr}$ 粒子の析出の活性化エネル ギーを与えると考えることができる。この值は先述した $\mathrm{Al}$ 中の $\mathrm{Zr}$ の拡散の活性化エネルギーにほぼ等しい。

$\mathrm{Al}-1.8 \% \mathrm{Cr}-1.7 \% \mathrm{Zr}$ 合金の時効硬化は主として結晶 粒内にみられた球状の $\mathrm{Ll}_{2}$ 構造をもつ準安定 $\mathrm{Al}_{3} \mathrm{Zr}$ 析出 粒子によると考えられたので， $\mathrm{Al}-\mathrm{Zr}$ 合金で $\mathrm{Al}_{3} \mathrm{Zr}$ 粒子 を微細に析出させるとされた $\mathrm{Si}$ を $\mathrm{Al}-\mathrm{Cr}-\mathrm{Zr}$ 合金に微 量添加することを試みた。Fig. 13 はとの結果の一例
で，いずれの時効温度とも微量の Si $の$ 添加は最高硬さ の値を高くしている。そして最高硬さに達する時効時間 も早くなつているよらである。 $\mathrm{Al}-1.8 \% \mathrm{Cr}-1.7 \% \mathrm{Zr}-$ $0.12 \% \mathrm{Si}$ 合金の単ロール法によるリボン状試料を電顕 観察したところ，急冷凝固時には何らの晶出物も認めら れなかつたので, $\mathrm{Cr}, \mathrm{Zr}$ とともに $\mathrm{Si}$ も $\mathrm{Al}$ 中に固溶して いたと考えられる。これを時効したものの明視野像は

Fig. $14(\mathrm{a})$ であるが(b)の暗視野像から多数の $\mathrm{Ll}_{2}$ 構造 の球状粒子の析出が認められた。なお, Si 相の存在を 示す回折斑点は認められなかつた。

\section{5. 結言}

$\mathrm{Al}-1.8 \% \mathrm{Cr}-1.7 \% \mathrm{Zr}$ 合金およびこれに $\mathrm{Si}$ を添加した 合金を単ロール法を用いて急冷凝固させ，得られたりボ ン状試料について時効硬化と析出組織を調べて，主に各 添加元素の効果について検討した。その主な結果は次の ようにまとめられる。

(1) $\mathrm{Al}-1.8 \% \mathrm{Cr}-1.7 \% \mathrm{Zr}$ 合金は時効硬化し， $\mathrm{Al}$ $1.7 \% \mathrm{Zr}$ 合金のそれよりも顕著であつた。これは $\mathrm{Cr} の$ 添加が $\mathrm{Al}-\mathrm{Zr}$ 合金に現れた粒界反応析出の進展を抑え て結晶粒内の微細な $\mathrm{Ll}_{2}$ 構造をもつ $\mathrm{Al}_{3} \mathrm{Zr}$ の析出をもた らしたためと考えられる。

(2) $\mathrm{Al}-1.7 \% \mathrm{Zr}$ 合金に $\mathrm{Cr}$ とともに微量の $\mathrm{Si}$ を添加 すると粒界反応析出が抑制された上に準安定相 $\mathrm{Al}_{3} \mathrm{Zr}$ 粒 子の微細析出が促進されると考えられた。Si の添加は このようにして到達硬さの值をさらに高くする効果をも つ。

本研究の費用の一部は軽金属奖学会グループ研究資金 の援助によつて行つた。記して謝意を表します。

\section{参 考 文 献}

1）堀, 佐治, 小林：金属学会誌, 24（1973）1134.

2) 堀, 佐治, 檜垣 : 軽金属, 25 (1975) 247.

3) 堀, 近藤, 池野 : ibid, 28 (1975) 79 .

4) I. R. Hughes, G. J. Marshall and W. S. Miller, "Proc. of 5th Int. Conf. on Rapidly Quenched Metals" eds, S. Steep and H. Warlimont, Elevier Science Publishers B. V., (1985) 1743.

5) S. P. Madson, R. A. Buckley and H. Jones, ibid., 923.

6) 木村，中野：軽金属，20（1970），481.

7）堀, 古城, 雲丹亀: 未発表.

8）堀，佐治：金属学会会報，20（1981），863.

9）堀, 雲丹亀, 古城, 田井：軽金属, 32 (1982), 408 . 